\title{
Effect of BMP-2 on Gene Expression of Enamel Matrix Proteins at the Dental Epithelial Cell Line
}

\author{
Liming $\mathrm{Xu}^{1}$, Ryoya Takahashi ${ }^{2}$, Hidemitsu Harada ${ }^{3}$ and Akiyoshi Taniguchi ${ }^{*}, 1$ \\ ${ }^{1}$ Cell-Sensing Group, Biomaterials Center, National Institute for Materials Science, 1-1 Namiki, Tsukuba, Ibaraki 305- \\ 0044, Japan \\ ${ }^{2}$ Department of Biochemistry, School of Pharmaceutical Sciences, Toho University 2-2-1, Miyama, Funabashi, Chiba \\ 274-8510, Japan \\ ${ }^{3}$ Department of Oral Anatomy II, Iwate Medical University, School of Dentistry, 1-3-27 Chuodori, Morioka, Iwate 020- \\ 8505, Japan
}

\begin{abstract}
Epithelial-mesenchymal interactions play an important role in the control of ameloblasts and odentoblasts differentiation, and the bone morphogenetic proteins (BMPs) are known factors that regulate the differentiation of ameloblasts. We examined the effect of BMP-2 on the expression of the enamel matrix protein genes at the dental epithelial cell line. BMP-2 induced a 3- to 4-fold increase in amelogenin and ameloblastin mRNA expression, suggesting that BMP-2 is important for ameloblast differentiation. This finding has potential application in the tissue engineering of tooth re-constructions.
\end{abstract}

\section{INTRODUCTION}

The interactions between epithelial and mesenchymal cells are thought to play an important role in the control of proliferation and differentiation of these cells. In tooth development, epithelial-mesenchymal interactions also play an important role in the control of ameloblast and odentoblast differentiation. Amelogenin and ameloblastin, which are major proteins of the enamel matrix produced by epithelial ameloblasts, are known to play a role in the regulation of mineralization of enamel $[1,2]$.

In recent years it has been reported that amelogenin regulates gene expression in the differentiation of some mesenchymal cells $[3,4]$. The specific amelogenin gene splice products induce expression of the bone matrix proteins bone sialoprotein (BSP) and BAG-75 in culture and in an implant in vivo [5]. We previously demonstrated that the reuptake of full-length amelogenin protein results in increased levels of amelogenin mRNA through enhanced mRNA stabilization $[6,7]$. These findings indicated that amelogenin proteins are important for both ameloblast and odentoblast differentiation in an autocrine or paracrine manner.

Bone morphogenetic proteins (BMPs) are also known factors that regulate terminal differentiation of ameloblasts and induce secretion of amelogenin [8-10]. BMP-2 is one of the most potent cytokines that stimulates osteoblast differentiation and bone formation [11,12]. BMP-2 functions to regulate the expression of transcriptional factors such as Pitx or Msx to mediate epithelial-mesenchymal interactions during tooth morphogenesis $[13,14]$. However, the effect of BMP-2 on the gene expression of the enamel matrix proteins is not well understood.

\footnotetext{
*Address correspondence to this author at the Cell Engineering Technology Group, Biomaterials Center, National Institute for Materials Science, 1-1 Namiki, Tsukuba, Ibaraki 305-0044, Japan; Tel: +81-29-860-4505; Fax: +81-29-860-4714; E-mail: TANIGUCHI.Akiyoshi@nims.go.jp
}

In the present study we examined the effect of BMP-2 on the gene expression of the enamel matrix proteins at the dental epithelial cell line. BMP-2 induced up-regulation of amelogenin and ameloblastin mRNA expression. This finding has potential application in the tissue engineering of tooth re-constructions.

\section{MATERIALS AND METHODS}

\section{Cell Culture}

HAT-7 cells, a dental epithelial cell line originating from the apical bud of a rat incisor $[6,7,15]$, were cultured in Dulbecco's Modified Eagle's Medium (DMEM)/F-12 (GIBCO BRL, USA) supplemented with $10 \%$ fetal bovine serum and penicillin $(100$ units $/ \mathrm{ml}) / \mathrm{streptomycin}(100 \mu \mathrm{g} / \mathrm{ml})$. All cultures were maintained in a humidified atmosphere of $5 \%$ $\mathrm{CO}_{2}$ at $37^{\circ} \mathrm{C}$. Recombinant human BMP-2 was purchased from R \& D Systems Inc. (USA, MN).

\section{RNA Extraction and Real-Time PCR Analysis}

The mRNA levels of differentiation-related marker genes were determined by quantitative real-time PCR as described previously [6,7,16-19]. Briefly, total RNA was extracted at various points with ISOGEN (Nippon Gene, Japan). A 4- $\mu \mathrm{g}$ amount of total RNA was reverse transcribed into cDNA with Super Script First-Strand Synthesis System (Invitrogen, USA) according to the supplier's protocol. Normalization was performed using the housekeeping gene, glyceraldehydes-3-phosphate dehydrogenase (GAPDH) expression as an endogenous control in the same reaction as the gene of interest. The primers for real-time PCR were designed with PrimerExpress software (AB Applied Biosystems) based on the sequence of the target gene. The primers were as follows: for amelogenin, forward: 5'-TGGGAGCCCTGGTTATATC AA-3', reverse: 5'-GCTGCCTTATCATGCTCTGGTA-3'; for ameloblastin, forward: 5'-TTCACCCAAGGGAGGAGA CTT-3', reverse: 5'-CTCTCCTTTCTCAGGGCCTTTAGT3'; for keratin 14, forward: 5'-GGACCTGAGCCGCATCCT- 
3', reverse: 5'-TCCACATCTTTGCGGTTCTTC-3'; for GAP DH, forward: 5'-GCCCCCAACACTGAGCAT-3', reverse: 5'-CCAGGCCCCTCCTGTTGT-3';

\section{RESULTS}

\section{Effects of BMP-2 on the Gene Expression of Enamel Ma- trix Proteins in HAT-7 Cells}

To investigate the effects of BMP-2 on dental epithelial cells, we analyzed the mRNA expression levels of enamel matrix protein genes and keratin 14 (as a control) in HAT-7 cells in the presence or absence of BMP-2. We found that $100 \mathrm{ng} / \mathrm{ml}$ of BMP-2 induced up-regulation of endogenous amelogenin and ameloblastin mRNA expression in HAT-7 cells (Fig. 1). No significant change in the expression of keratin 14 was observed, and thus enamel matrix protein genes might be specifically regulated by BMP-2 in HAT-7 cells.

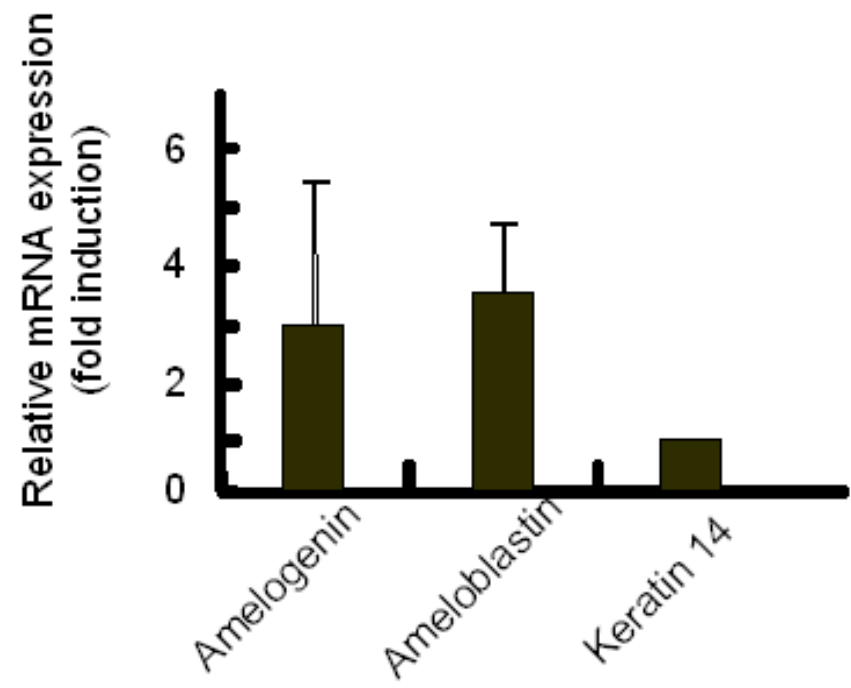

Fig. (1). Effect of BMP-2 treatment on the gene expression of enamel matrix proteins and keratin. HAT-7 cells were treated with $100 \mathrm{ng} / \mathrm{ml}$ BMP-2 for 3 days and mRNA expression measured by real time RT-PCR. Data were normalized to non-treatment gene expression. Each column represents the mean+S.D. $(n=4)$.

\section{Expression Time-Course of Ameloblastin Gene Expres- sion After Treatment with BMP-2}

To determine the expression time-course of the ameloblastin gene, quantitative real-time RT-PCR analysis was performed on HAT-7 cells that had been treated with BMP-2 for 0, 1, 2 or 3 days. As shown in Fig. (2), BMP-2 induced ameloblastin mRNA expression in a time- and dosedependent manner. These results suggest that BMP-2 induces enamel matrix protein genes in dental epithelial cells.

\section{DISCUSSION}

BMP-2 signaling consists of a receptor complex that activates Smads and a Smad-containing complex that controls transcription of the downstream target genes, with DNAbinding factors, such as CREB-binding protein(CEP)[20]. The promoter structures of amelogenin and ameloblastin have been identified [21-23]. The amelogenin promoter contains regulatory elements of CEP. This suggests that BMP-2 activates transcription of amelogenin gene through CEP.
It has been reported that BMP-2 was detected at the apical and basal poles of preameloblasts in the developing mouse first lower molar [24], and, BMP-2, which induces ameloblast differentiation in vitro enamel organ culture [9]. These studies suggested that BMP-2 play a role on the ameloblasts differentiation. It has been also shown that BMP-2 and BMP-4 were expressed in the enamel knot, and they may play an important role in the control of tooth morphogenesis $[25,26]$. Amelogenin and ameloblastin are two major enamel matrix proteins, counting for $90 \%$ and 5 $10 \%$ of enamel matrix proteins, respectively. Our results showed that BMP-2 induced amelogenin and ameloblastin mRNA expressions in the ameloblast-like cell line. These findings will provide a molecular evidence of that BMP-2 induced the differentiation of ameloblasts.

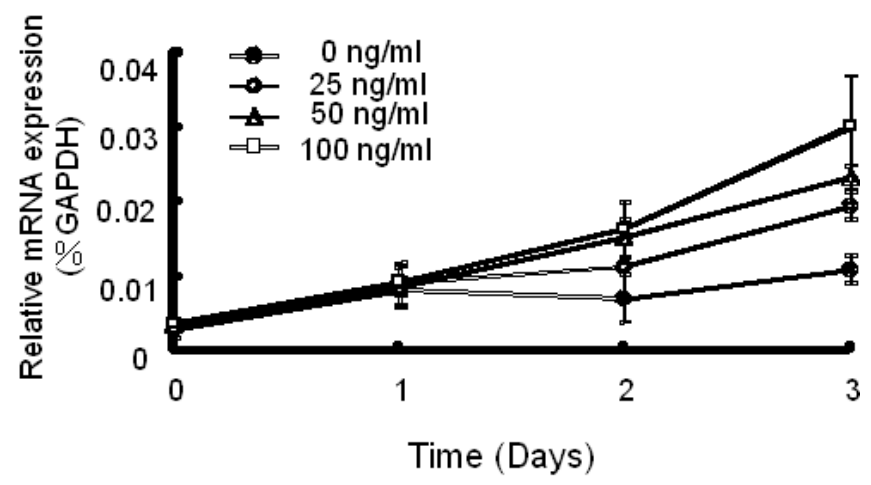

Fig. (2). The expression time-course of ameloblastin gene expression after treatment with BMP-2. Ameloblastin mRNA expression was measured by real time RT-PCR. Data were normalized to glycerol aldehyde dehydrogenase gene expression. Data represents the mean+S.D. $(n=4)$.

\section{REFERENCES}

[1] Termine JD, Belcourt AB, Christner PJ, Conn KM, Nylen MU Properties of dissociatively extracted fetal tooth matrix proteins. I. Principal molecular species in developing bovine enamel. J Biol Chem 1980; 255: 9760-8.

[2] Fukumoto S, Yamada A, Nonaka K, Yamada Y. Essential roles of ameloblastin in maintaining ameloblast differentiation and enamel formation. Cells Tissues Organs 2005; 181: 189-95.

[3] Viswanathan HL, Berry J E, Forster BL, and Gibson CW. Amelogenin: a potential regulator of cementum-associated genes. J Periodontol 2003; 74: 1423-31.

[4] Boabaid F, Gibson CW, Kuehl MA, Berry JE, Sneed ML, Nociti FH Jr, Katchburian E, and Somerman MJ. Leucine-rich amelogenin peptide: a candidate signaling molecule during cementogenesis. $\mathrm{J}$ Periodontol 2004; 75: 1126-36.

[5] Veis A, Tompkins K, Alvares K, Wei K, Wang L, Wang XS, Brownell AG, Jengh S-M, and Healy KE. Specific amelogenin gene splice products have signaling effects on cells in culture and in implants in vivo. J Biol Chem 2000; 275: 41263-72.

[6] Xu L, Harada H, Tamaki Y-T, Matsumoto S, Tanaka J, Taniguchi A. Reuptake of extracellular amelogenin by dental epithelial cells results in increased levels of amelogenin mRNA through enhanced mRNA stabilization. J Biol Chem 2006; 281: 2257-62.

[7] $\mathrm{Xu} \mathrm{L}$, Harada $\mathrm{H}$, Taniguchi, A. The exon $6 \mathrm{ABC}$ region of amelogenin mRNA contribute to increased levels of amelogenin mRNA through amelogenin protein-enhanced mRNA stabilization. J Biol Chem 2006; 281: 32439-44.

[8] Goldberg M, Six N, Decup F, Lasfargues JJ, Salih E, Tompkins K, and Veis A. Bioactive molecules and the future of pulp therapy. Am J Dent 2003; 16: 66-76.

[9] Coin R, Haikel Y, and Ruch JV. Effects of apatite, transforming growth factor beta-1, bone morphogenetic protein-2 and interleukin-7 on ameloblast differentiation in vitro. Eur J Oral Sci 1999; 107: 487-95. 
[10] Xu X, Jeong L, Han J, Ito Y, Bringas P Jr, Chai Y. Developmental expression of Smad1-7 suggests critical function of TGF-beta/BMP signaling in regulating epithelial-mesenchymal interaction during tooth morphogenesis. Int J Dev Biol 2003; 47: 31-9.

[11] Hogan BL. Bone morphogenetic proteins: multifunctional regulators of vertebrate development. Genes Dev 1996; 10: 1580-94.

[12] Canalis E, Economides AN, Gazzerro E. Bone morphogenetic proteins, their antagonists, and the skeleton. Endocr Rev 2003; 24 : 218-35.

[13] Tucker AS, Al Khamis A, Sharpe PT. Interactions between Bmp-4 and Msx-1 act to restrict gene expression to odontogenic mesenchyme. Dev Dyn 1998; 212: 533-9.

[14] Jernvall J, Aberg T, Kettunen P, Keranen S, Thesleff I. The life history of an embryonic signaling center: BMP-4 induces p21 and is associated with apoptosis in the mouse tooth enamel knot. Development 1998; 125: 161-9.

[15] Kawano S, Morotomi T, Toyono T, Nakamura N, Uchida T, Ohishi M, Toyoshima K, Harada H. Establishment of dental epithelial cell line (HAT-7) and the cell differentiation dependent on Notch signaling pathway. Connect Tissue Res 2002; 43: 409-12.

[16] Takayama G, Taniguchi A, Okano T. Identification of differentially expressed genes in hepatocyte/endothelial cell co-culture system. Tissue Eng 2007; 13: 159-66.

[17] Ishibashi Y, Inouye Y, Okano T, Taniguchi A. Effects of carbocisteine on sialyl-Lewis $\mathrm{x}$ expression in NCI-H292 cells, an airway carcinoma cell line, stimulated with tumor necrosis factor- $\alpha$. Eur J Pharmacol 2006; 530: 223-28.
[18] Kurosawa Y, Taniguchi A, Okano T. A novel method to examine hepatocyte specific gene expression in a functional co-culture system. Tissue Eng 2005; 11: 1650-57.

[19] Ishibashi Y, Inouye Y, Okano T, Taniguchi A. Regulation of sialylLewis $\mathrm{x}$ epitope expression by TNF- $\alpha$ and EGF in an airway carcinoma cell line. Glycoconj J 2005; 22: 53-62.

[20] Feng XH, Derynck R. Specificity and versatility in TGF-beta signaling through Smads. Annu Rev Cell Dev Biol 2005; 21: 659-693.

[21] Zhou YL, Snead ML. Identification of CCAAT/enhancer-binding protein alpha as a transactivator of the mouse amelogenin gene. $\mathrm{J}$ Biol Chem 2000; 275: 12273-80.

[22] Zhou YL, Lei Y, Snead ML. Functional antagonism between Msx2 and CCAAT/enhancer-binding protein alpha in regulating the mouse amelogenin gene expression is mediated by protein-protein interaction. J Biol Chem 2000; 275: 29066-75.

[23] Lee SK, Kim SM, Lee YJ, Yamada KM, Yamada Y, Chi JG. The structure of the rat ameloblastin gene and its expression in amelogenesis. Mol Cells 2003; 15: 216-25.

[24] Nadiri A, Kuchler-Bopp S, Haikel Y, Lesot H. Immunolocalization of BMP-2/-4, FGF-4, and WNT10b in the developing mouse first lower molar. J Histochem Cytochem 2004; 52: 103-112.

[25] Aberg T, Wozney J, Thesleff I. Expression patterns of bone morphogenetic preteins (Bmps) in the developing mouse tooth suggest role in morphogenesis and cell differentiation. Dev Dyn 1997; 210: 383-396.

[26] Peterkova R, Peterka M, Vonesch JL, Tureckova J, Viriot L, Ruch $\mathrm{JV}$, Lesot $\mathrm{H}$. Correlation between apoptosis distribution and BMP2 and BMP-4 expression in vestigial tooth primordial in mice. Eur J Oral Sci 1996; 106: 667-670. 